\title{
Threonine Aspartase 1
}

National Cancer Institute

\section{Source}

National Cancer Institute. Threonine Aspartase 1. NCI Thesaurus. Code C102896.

Threonine aspartase 1 (420 aa, $44 \mathrm{kDa}$ ) is encoded by the human TASP1 gene. This

protein plays a role in the proteolysis of histone-lysine $\mathrm{N}$-methyltransferase MLL protein. 